\title{
Confessions of a Muslim Humanist ${ }^{*}$
}

Enes Karić

*In 2020, a new publication of Sjećanja [Memories] has come out regarding the memoires of Alija Izetbegović, the first president of Bosnia and Herzegovina from 1991-1996. To mark the publication, I have written the following commentary which was published last year in Bosnian. This review of his Sjećanja was written as a retrospective review of the receptions of his work over the past 20 years. ${ }^{1}$

In the work Grundphänomene des menschlichen Daseins [The Basic Phenomena of Human Existence], German philosopher Eugen Fink (1979) argues human life on the whole to develop and unfold within five phenomena lastingly present in manifold and parallel forms: work, love, power, play, and death. Furthermore, Fink concluded human life to mostly end, bend, and form mainly within these five fundamental and overarching phenomena of human existence.

1 The writing of this review was supported by the Alija Izetbegović Museum as well as the Islamic informative newspaper Preporod.

@

Prof. Dr., University of Sarajevo. eneskaric@yahoo.com

https://orcid.org/ 0000-0003-2954-4442

(C) İlmi Etüdler Derneği

DOI: $10.12658 / R 0026$

insan \& toplum, 2021.

insanvetoplum.org 
Excluding the phenomenon of play, on which Sjećanja contains little information, ${ }^{2}$ the life of Alija Izetbegović (1925-2003) is thickly woven from at least the four remaining phenomena of human existence and their manyfold planes. This may precisely be the reason that reading his Sjećanja (Izetbegović, 2005, p. 31) can hardly make anyone indifferent. The reasons behind this are many, which every reader discovers in their own way, but the main ones can be linked to the fact that Sjećanja defies being just read as a personal story about the past life of a man, in this particular case the personal story about the life of Alija Izetbegović; instead, the pages of this lengthy confession are sifted through and understood as testimonies of an epoch in its numerous sections and segments, particularly of the intense times following 1990.

Various receptions of Alija Izetbegovićs Sjećanja share many similarities with those looming from the An Autobiography: The Story of My Experiments with Truth by Mahatma Gandhi (1927), ${ }^{3}$ The Days by Taha Hussein (1979), ${ }^{4}$ and many other biographies of prominent persons of the $19^{\text {th }}$ and $20^{\text {th }}$ centuries. Their autobiographies are often powerful acknowledgements of the lives lived not only by them but by the thousands or even millions of their contemporaries.

\section{Life in Almost Nine Decades}

Alija Izetbegović should be believed when he says the following about his Sjećanja: "These are fragments of my life, because I have either forgotten whole parts of my life or they are mine and mine alone. Even what is left is more of a chronicle rather than a biography" (Izetbegovic, 2005, p. 17). This disclosure informs the reader that the author has excluded two planes from Sjećanja: the forgotten parts of his life and those parts that are personal to him which he did not share with others because he saw no reason to.

This exact reasonability and purposefulness of his Sjećanja is what Alija Izetbegović explains in the introduction titled "A Short History of Bosnia and Herzegovina

2 Alija Izetbegović mentions his mother's homestead in Azići where he'd go with his peers during the summer: "These summer days spent in the country are certainly the best days of my life." (Izetbegović, 2005, p. 31). This is almost all that he conceivably said about the parts of his youth that also contained the element of play.

3 Published in Serbian, Croatian and Bosnian in several editions.

4 As far as we know, there are two translations of Days, an autobiography by Taha Hussein. The first translation was made by Nijaz Dizdarević, published by Svjetlost in 1979, and the other one by Esad Duraković, published by Svjetlost in 1998. 
(according to Noel Malcolm)" (Izetbegovic, 2005, pp. 19-25). Offering a history of Bosnia and Herzegovina, the author indicates that his Sjećanja mostly portrays the turbulent part of his life in a way that has been codefined by the recent history of his homeland. Sjećanja further unfolds and leafed through chapter by chapter as a riveting read through all its seething times and fundamental developments, brimming with descriptions of the good and bad deeds of people who had left a mark, whether short- or long-term, not only on the author's life but also on his homeland of Bosnia and Herzegovina (this is particularly true of the canvas of time after 1990).

Using a clear and also respectable literary style to describe his youth and first imprisonment from 1946-1949 in Chapter One, the author just briefly performs a memorial and emotional pilgrimage of the past, the lives of his ancestors, his Belgrade origin, moving into Bosanski Šamac (where he was born in 1925), the subsequent move to Sarajevo, his schooling, World War II, and Sarajevo's bleak post-war period. Sjećanja then quickly shifts with the author's outlook and perspective, following the years of Socialism, the time of his first imprisonment, his later schooling, and the literature that had a crucial impact on his intellectual maturation and understanding of the world within and beyond him. It also includes his testimonies regarding how he had produced his works The Islamic Declaration (1999) and Islam between East and West (1984), as well as a description of the ideals he had closely embraced while writing these two books. In the following part of Sjećanja, the author mentions the jobs he had held until the early 1980's.

The spot where the reader can notice a major turning point in Sjećanja is the description of the author's life in the memorable year of 1983. Chapter Three offers a faithful description of the trial of 12 Muslim intellectuals in Sarajevo. The months of investigation and the proceedings are frequently described with sarcasm, with the first years in prison being recounted wistfully and impressively accompanied by the terrible realization that he had been sentenced to 14 years in prison!

Many passages from Izetbegović's Sjećanja here resemble Fyodor Mikhailovich Dostoevsky's descriptions in The House of the Dead (1862). Then in November 1988, another radical change took place and Alija Izetbegović was released from prison. The author's life progressed now in a sort of symbiosis with the founding of the Party of Democratic Action (Stranka demokratske akcije [SDA]) in May 1990. In November of the same year, the SDA won the first multiparty elections in Bosnia and Herzegovina since 1945. The author, a former political prisoner as he was, entered politics now as one of its main protagonists in Bosnia and Herzegovina.

Sjećanja goes on to consistently refer to the author's life, which he now lived in the form of increasingly intense political engagement and statesmanship. The 
socialist Yugoslavia would soon disintegrate, or rather be torn apart in 1991-1992, and the author speaks about his political contribution to saving Yugoslavia. "I used to love Yugoslavia," he says in his Sjećanja, while in a different place he offers the following explanation:

I was emotionally attached to Yugoslavia and, perhaps as a Muslim, I instinctively felt that the break-up of Yugoslavia was not in our favor. Even though the highest concentration of Muslims was in Bosnia, Muslims were also in Serbia, Montenegro, Macedonia, Kosovo, and Croatia. (Izetbegovic, 2005, p. 76)

Then Chapter Four has pages of Sjećanja that are full of descriptions of the brutal aggressions and cataclysm of the Bosnian War from 1992-1995. The Srebrenica genocide is described in Chapter Five, while Chapter Six has Sjećanja put a spotlight on the many negotiating initiatives as well as attempts and labyrinths, ones where the author often saw that not only himself but also many others who had not betrayed their human heart and moral upstanding had been caught up in Kafkaesque forms of the demiurgic machineries of global diplomacy that easily get the better of an individual. "The Dayton Diaries" makes Chapter Seven, and "After Dayton" is Chapter Eight, the final chapter dedicated to the second post-war period the author experienced, but now undoubtedly as a morally encouraged man whose human deeds and political fights had saved Bosnia and Herzegovina as a state.

This is the external structure of Alija Izetbegović's Sjećanja whose structure addresses the author's approximately 80 years. Still, Alija Izetbegović's Sjećanja have its powerful internal stems and threads. It is now time to say the most important things about them.

\section{Sjećanja from the Crossroads of Worlds}

Sometimes the lives of later people so happen to often emerge as an inevitable interpretation of the lives of the people before them. As is the case with many lives, so is this with many books, particularly when leafed through and read so as to bring their pages into conversation. A good example of this may be found in Selimović and Jerkov's (2004, p. 310) novel Derviš i smrt [Death and the Dervish], where through the hero Hasan, they say, "We live at a crossroads of worlds, at a border between peoples, in everyone's way."

The literature and non-literary works in Bosnia and Herzegovina hardly contain a work that would more impressive for interpreting the quote from Derviš $i$ smrt Selimović and Jerkov's (2004) than Alija Izetbegović's Sjećanja. For more than half 
the book, Izetbegović's Sjećanja rather directly shows the harsh times the people of Bosnia and Herzegovina experienced, the people whom Meša Selimović confirms to have the fate of being at a crossroads of worlds, to lastly die a slow death on the border between peoples and thus be in everyone's way.

The narrative magic of Alija Izetbegovićs Sjećanja hides in the fact that the author lacked any narrative mission apart from closely and faithfully speaking about the events that had taken place in the years of the great exchange of times, ${ }^{5}$ an exchange that addressed the memorable and revolutionary decade from 1990 to 2000. Hence, Sjećanja appears as an uncommon collection of uncommon memories from times that were anything but idle. In Sjećanja, the author is not merely a chronicler, literary author, writer, or one who follows the exchange of times from his exclusive idleness and inclination from somewhere out there. On the contrary, the author of Sjećanja is in the midst of the scene with many and carries on his shoulders the burden of the huge political responsibility of a political headman. Although he is not the only one creating the scene, he suffers the blows of so-called interesting times. A cruel war rages with genocide, one that savagely persecutes the population. The Bosnia and Herzegovina as it used to be known disappeared during its precursory almost millennial trajectory.

An undoubtedly powerful stamp is also made on Sjećanja by virtue of the fact that Alija Izetbegović had been the President of Bosnia and Herzegovina or a Presidency member for quite a while (1990 - 2000) and had also been the indisputable political leader of Bosnia and Herzegovina and Bosniaks (1990 - 2003). I point this out namely because all too often political vocabulary and political discourse can be terribly boring. However, Alija Izetbegović neither intertwines in or dominates his Sjećanja with bland political discourse. Quite conversely, Sjećanja offers a close picture of the aggression against Bosnia and Herzegovina, and the Bosnian War from 1992-1995 represents an intense time akin to a conflagration that consumes everything including itself. This time was when Alija Izetbegović, together with the people and patriots of this country, lived in every sense of the word through as much as someone else would in 50 or a 100 years.

The other of Sjećanja read smoothly and dynamically as they describe a life that was rushing by and the everyday life of a war (1992 - 1995) with many deaths through killing and executions, besieged towns, constant shelling and massacres, blocked districts, halted convoys, refugees and expelled persons received, ethnic cleansings, 
harsh winters, and prisoner exchanges. Here, Sjećanja is neither a product of a later perception nor a subsequently written text where the descriptions and analyses appear post festum. On the contrary, Sjećanja is contemporary and concordant with the historical terror of a slighted life of besieged towns, shelling, massacres, harsh winters and scorching summers in towns with no utilities whose streets echoed with the explosions of shells, the reek of sewage, and the stench of decomposing human and animal bodies.

If Alija Izetbegović gained any satisfaction after the hell he went through alongside all those who lovingly fought for the survival of the state of Bosnia and Herzegovina, it would be precisely for Sjećanja in which he publishes his speeches, narratives, accounts, addresses, interviews, encouragements, urges, cries, and entreaties. He published the book not as a subsequently polished image or nicely framed picture but as the simultaneous and direct consequences of the war, suffering, torment, and cataclysm. All that he writes about in Sjećanja is significant because it is not formulated nor subsequently dispatched from a distanced, stylistically polished hindsight. Instead, the work rather looms as a powerful and clear voice from the middle of the Bosnian hell, often in frightening reality; it is an image of a terrifying picture showing a hand appearing from a fresh grave. In this sense, Sjećanja is a first-rate historical source precisely because its content is documented and positioned relative to the actual questions of who, when, where, how, and why. This is why Sjecanja is read and will be read for a long time as a book about the tribulations of those at the crossroads of worlds.

\section{The Voice of a Muslim Humanist}

Based not just on Sjećanja but also his other books, Alija Izetbegović can best be described as a Muslim humanist. The first word of the phrase clarifies his spiritual roots in Islam, while the other sheds some light on his trust in the humanist traditions of the West and the world in general. Calling Alija Izetbegović a Muslim humanist is still in line with Selimović's observation about being at the crossroads of worlds. Alija Izetbegović was acutely aware of these worlds and even more so of their crossroads. He offered a synthesis. Sjećanja testifies to this on a number of planes in many chapters.

At the height of the horrors of war when no reasonable word was expected from any side, Alija Izetbegović, despite being a politician amidst difficult times, also became engaged in newspaper, television, and radio interviews, sending out the messages: "We tried to preserve Yugoslavia on the condition that Croatia remains 
within it as well," "We are fighting for a Bosnia and Herzegovina in which no one will suffer on the grounds of their faith, nation and beliefs," and "Let us negotiate whenever we can and make war when we must." Sjećanja conveys these messages of his as testaments: He did not think he was saying these in vain but that there were people who would hear them.

Sjećanja clearly shows all the roads that Muslim humanist Alija Izetbegović has travelled and mentions all the important world destinations to which he brought his messages about the hardships of Bosnia and Herzegovina and its people. Across the world, Alija Izetbegović has warned about the torments of the people in Bosnia and Herzegovina fighting against the war, repeating the words he first said at his speech at the SDA convention on December 1, 1991:

Should the gunpowder barrel explode, everything would disappear in smoke and disgrace, both cartographers and generals, and all the parties and all the leaders, all the laws and institutions, and the major part of what has been built in this territory through the hard work of dozens of generations. Since they are unlucky enough to be indestructible, the three bleeding and defeated peoples will remain alone, losing their minds and being reduced to the level of barbarity. (Izetbegovic, 2005, pp. 114-115)

Unfortunately, in the turbulence of 1992, the gunpowder barrel exploded. Sjećanja offers documents with authentic data about the times and places (e.g., London, Lisbon, Geneve, Rome, Paris, Vienna, Washington, New York, Dayton, Riyadh, Jeddah, Teheran, Casablanca) where Alija Izetbegović had spoken, warned, requested, pleaded, and moved the knockers on the gates of the world's powerful people.

For this reason, his Sjećanja has an international dimension as well a local one. Such chapters from this valuable book are at times drenched in pessimism and at others with the author's huge disappointment at the (lack of) readiness of the major centers of global power to defend the principles they themselves proclaim. These are the pages in Sjećanja where the author questions his long-standing upholding of the concepts of the Muslim humanists. Whenever he would visit the major centers of the Muslim East (e.g., Riyadh, Teheran), he would challenge his Muslimhood, whereas in the Western capitals, he would question his humanist viewpoints. Sjećanja faithfully speaks about its author as a man in the middle, searching for the midway solutions and remaining constantly open to all the sides of the world that the phrase Muslim humanist implies.

In several places of his Sjećanja, the author brings selections from his speeches about Bosnia and Herzegovina held at important summits and conferences where he warns not only the survival of the state of Bosnia and Herzegovina to be at stake but also the survival of its society. He reminds the European Union that the EU itself 
is exactly striving toward building the multilateral society that has existed in Bosnia and Herzegovina for centuries. Today, almost three decades since Izetbegović had stated his warnings, his key words mentioned in numerous pages of Sjećanja can be seen to have emerged from the very reality of this part of the world. His words and warnings have not expired but remain as unignorable ideals.

According to Sjećanja, Alija Izetbegović also appears in all his addresses from 1990 to $2000^{6}$ as a Muslim European, ${ }^{7}$ as a man of an East-West synthesis, and as a statesman and intellectual recognized for his inclusive positions, attitudes, and opinions. However, Sjećanja very intimately, bitterly, and painfully speaks about the meetings Alija Izetbegović had with everything flowing downstream from those times: the war and aggression, cruel adversaries, cunning politicians, brutal negotiators, indifferent cartographers, scheming mediators, courtesy envoys, powerful world statesmen, provincial para-statesmen, humanitarians, humanists, world religious leaders, criminals, traitors, military leaders, mannequins and war dogs, international peacemakers, plain soldiers, and refugees. ${ }^{8}$

Occasionally albeit rarely, Sjećanja testifies to a despondent author who's been left alone with his realizations that there is no way out, to one who is the head of a people left with no choice, and to one who represents the state of Bosnia and Herzegovina neglected by the global powers and decisionmakers. These are the pessimistic sections, rare and temporary, on some of Sjećanja pages. Then suddenly hope springs anew of the kind mentioned in the sayings he heard from a dignitary in the United Arab Emirates: "Be patient, President Izetbegović! Even the longest droughts end in fertile rains.”

On many of its pages, Sjećanja very directly speaks about the two faces of the contemporary world, particularly in the period of 1990-1995. A one- or two-hour flight from Sarajevo where he often went for peace negotiations, the European capitals lived in luxury and light and in the blessing of peace and prosperity. Certainly, every time he returned home to Sarajevo and Bosnia, this Muslim humanist had been reassured that, despite the summits and conferences, the fierce war continued alongside the harsh winters, snow, fog, and low clouds of hopelessness over the country besieged in several rings. And despite all this, the author of Sjećanja never

\footnotetext{
6 On this period of Izetbegovićs political engagement one might want to consult a very studious work by Admir Mulaosmanović, Iskušenje opstanka, Izetbegovićevih deset godina 1990.-2000. (Ordeal of Survival - Izetbegović's Ten Years 1990-2000), Dobra knjiga, Sarajevo, 2013.

7 I owe this phrase to Professor Hilmo Neimarlija.

8 We said these few lines at the first launch of Sjećanja in Sarajevo, 6 July 2001.
} 
betrayed his ideals of either Muslimhood or humanism, nor did he ever accept the shortcut explanation of the anti-Bosnian war and aggression according to which a conspiracy theory lay behind it. On the contrary, he tried to find solutions and ways out of the terrible cataclysm of Bosnian suffering using the mind and reason, justice and law, and regulations and procedures. In the end, Bosnia and Herzegovina are preserved as a single state, while Alija Izetbegović has several times been characterized as the moral winner.

\section{Sjećanja in Contexts}

Twenty years have passed since the first edition of Sjećanja by Alija Izetbegović. ${ }^{9}$ These two decades have been a canvas of time ensuring a sufficient historical distance for many studies of this exceptional work. In addition, Sjećanja has had an undoubtedly huge international reception in terms of reading and analysis, particularly regarding its translations into English as Inescapable Questions, Autobiographical Notes (2001), Turkish as Tarihe Tanıklı̆̆ım (2003), and Arabic as Sīrah dātiyyah wa as ílah lā mafarra $\operatorname{minhā~(2004).~}$

For this particular reason, Sjećanja should nowadays be read and studied within several contexts that must not be neglected. The context of time, the present time, and that addressed in Sjećanja require critical comparisons. In this regard, importance is had in bearing in mind the maxim that the author expresses several times in Sjećanja and that describes Bosnia as a severely hurt patient who needs help and IV fluids administered by the international community in order to recover and stand on their feet. To what extent is Bosnia and Herzegovina a patient today, and to what extent is the international community a healer? Sjećanja is a good basis for studying this topic; it is a mirror reflecting the principles proclaimed by international law 25 years after the Bosnian disaster.

Today, Sjećanja should also be read and juxtaposed with the other works by Alija Izetbegović, such as the ones he wrote in the times of his ideals or before going to his long imprisonment (1983), such as Islamska deklaracija [The Islamic Declaration] and Islam izmedu Istoka i Zapada [Islam Between the East and the West]; equally, Sjećanja should also be critically read and studied in comparison with the other memoirs of numerous significant figures who entered the political scene in the late $20^{\text {th }}$ and early $21^{\text {st }}$ centuries. This is particularly relevant to the 
persons who were heavily involved in saving Bosnia from the jaws of war and downfall between 1992-1995.

Directly or indirectly, the Bosnian cataclysm on one hand and the salvation and preservation of Bosnia and Herzegovina as a state on the other produced a large amount of closely specialized academic and university literature. Sjećanja by Alija Izetbegović should be comparatively studied relative to this academic production focusing on the Balkan upheavals between 1990-2000. The work by Edina Bećirević (2014) titled Genocid na rijeci Drini [Genocide on the Drina River] is a study published by one of the most prestigious contemporary publishers and is important as the further unmasking and interpretation of the causes, effects, and consequences of the anti-Bosnian war. Alija Izetbegović's stances, opinions, and political moves he discusses in Sjećanja should be further researched in the context of the research of Edina Bećirević. In addition, alongside Admir Mulaosmanović's (2013) work Iskušenje opstanka, Izetbegovićevih deset godina 1990.-2000. [Ordeal of Survival - Izetbegovićs Ten Years 1990-2000]. and the other works of Alija Izetbegović in addition to Sjećanja should be viewed in a critical analysis such as the ones done by Tarik Haverić in his two works Etnos i demokratija [Ethnos and Democracy (2006)] and Kritika bosanskog uma [The Critique of the Bosnian Mind (2016)].

Bosna and Hercegovina and its long-time President Alija Izetbegović have had the grim fate of being frequently mentioned in the memoirs of the leading figures of global politics. The discourses from works such as My Life (Clinton, 2004), Madame Secretary (Albright, 2003), To End a War (Holbrooke, 1998), A Problem from Hell: America and the Age of Genocide (Power, 2002), Origins of a Catastrophe: Yugoslavia and Its Destroyers (Zimmerman, 1996), Waging Modern War: Bosnia, Kosovo, and the Future of Conflict (Clark, 2001), almost a world library of memoirs, appear as both a testament and analytical literature on Bosnia and Herzegovina in the late $20^{\text {th }}$ and early $21^{\text {st }}$ centuries.

If read in the context of a dozen of books published locally and in the world, as well as in the context of the hundreds of studies focusing on the difficult and turbulent years that befell the Balkans, not only Sjećanja but also the other works by Alija Izetbegović appear as largely different reads, as books to which later times and receptions are not indifferent. In particular, many receptions of Sjećanja emerge as studying the precise book offering a diagnosis of a horrible catastrophe between 1992-1995, a diagnosis that has remains undisputed.

Even though Sjećanja represents a collection of autobiographical notes, it remains vital in its diagnostic objectivity even without its author. Thus, the authorial has become historical. 
The world is entering the third decade of the $21^{\text {st }}$ century, and the political ideals of the future Sjećanja claims should be based on humanity, accountability, good deeds, and morality, should be hoped to have gained its place in the politics of the Balkans and Southern Europe.

Izetbegović's Sjećanja remains vital as a witness of times when the powerful world kept turning its head from the tragedy in Bosnia and Herzegovina. Still, this honest book testifies to the fact that millions across the world could not turn away their hearts.

\section{References}

Albright, M. (2003). Madame secretary. Miramax Books.

Baltić, J. (1991) Godišnjak od dogadjaja i promine vrimena u Bosni 1754 - 1882. Veselin Masleša.

Bećirević, E. (2014) Genocide on the Drina River. Yale University Press.

Bīgūwitš, A. I. (2004) Sīrah dِātiyyah wa as ílah lā mafarra minhāa, Dāru l-Fikr.

Clark, W. K. (2001). Waging modern war: Bosnia, Kosovo, and the future of conflict. Public Affairs Books.

Clinton, W. (2004). My life (J. Cooper, Ed.). Knopf Publishing Group Random House.

Fink, E. (1979). Grundphänomene des Menschlichen Daseins. Alber-Broschur Philosophie.

Gandhi, M (1927). An autobiography: The story of my experiments with truth. Public Affairs Press.

Haverić, T. (2006). Etnos i demokratija, Rabic.

Haverić, T. (2016) Kritika bosanskog uma. ECLD.

Holbrooke, R. (1998). To end a war. Penguin Random House.

Hussein, T. (1979). The days. (Nijaz Dizdarević, Trans.). Svjetlost.

Hussein, T. (1998). The days. (Esad Duraković, Trans.). Svjetlost.

İzzetbegoviç, A. (2003) Tarihe Tanıklığım, Klasik.

Izetbegović, A. (2003) Inescapable questions, autobiographical notes (S. Risaluddin \& J. Izetbegović, Trans.). The Islamic Foundation.

Izetbegović, A. (2005). Sjećanja. OKO.

Mulaosmanović, A. (2013) Iskušenje opstanka, Izetbegovićevih deset godina 1990.-2000. [Ordeal of Survival - Izetbegovićs Ten Years 1990-2000]. Dobra knjiga.

Power, S. (2002). A problem from hell: America and the age of genocide. Basic Books.

Selimović, M., \& Jerkov, A. (2004). Derviš i smrt [Death and the Dervish]. NIN.

Zimmerman, W. (1996). Origins of a catastrophe: Yugoslavia and its destroyers. Times Books. 